\title{
EXCEPTIONAL MANITOBA BIRD RECORDS OF 2014
}

\section{CHRISTIAN ARTUSO ${ }^{1}$ AND RUDOLF KOES ${ }^{2}$.}

1. Birds Studies Canada, Manitoba Breeding Bird Atlas Coordinator. Box 24, 200 Saulteaux Crescent, Winnipeg, MB, R3J 3W3, Email: cartuso@birdscanada.org Toll-free telephone: 1-800-214-6497 2. 135 Rossmere Crescent, Winnipeg, MB, R2K 0G1, Email: rkoes@mts.net

Manitoba was graced with a series of exceptional rarities in 2014, including our first Blackthroated Sparrow, first modern records of Swallow-tailed Kite and MacGillivray's Warbler, and, most exceptional of all, our first Mississippi Kite which was also the first confirmed breeding record for Canada. The latter was the fifth species that Manitoba Breeding Bird Atlas (www.birdatlas.mb.ca) field work has added to Manitoba's list of confirmed breeding bird species. Also documented were the second confirmed records of Black Vulture and Eurasian Tree Sparrow and the first possible breeding record of Yellow-billed Loon.

\section{Yellow-Billed Loon}

As part of a 10-day out-trek in extreme northern Manitoba near the Hudson Bay coast, Ken Kingdon and the senior author recorded a Yellow-billed Loon $5 \mathrm{~km}$ north of the Caribou River and $21 \mathrm{~km}$ inland. On 21 June, Kingdon heard loon calls that were similar to Common Loon. Since
Red-throated and Pacific loons are the only two expected species in this area, Artuso searched the area and subsequently observed a Yellow-billed Loon in flight over a narrow channel between two lakes. The lighting and viewing conditions were excellent and the bird's massive size, black and white plumage, and bright yellow bill were clearly visible. It is not known if this was a single bird summering south of the usual range or a breeding effort. There are nine other records for Manitoba, one from southern Manitoba and eight from the mouth of the Churchill River, all of which are thought to pertain to migrants. Sightings just north of Manitoba on Neultin Lake in 1947 may pertain to local breeders. ${ }^{1}$

\section{Black Vulture}

On 30 March 2014, Manitoba's second confirmed (third overall) Black Vulture flew over counters at the Windygates (Pembina Valley) Hawk Watch (photo: Raymond Klassen). There was also a later unconfirmed report of 


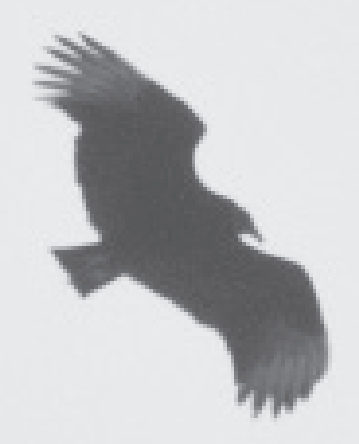

a Black Vulture near Whitemouth on 18 August. Interestingly, Saskatchewan's second sighting of a Black Vulture was a bird seen in Weyburn on 19 Apr 2014 (C. Bjorklund fide A. R. Smith).

\section{Swallow-tailed Kite}

On 22 May 2014 a group of flag-football players and coaches noticed a large bird flying overhead in Fraser's Grove Park, East Kildonan, Winnipeg. This park, located along the Red River, contains both grassy areas and mature deciduous river-bottom forest. The bird remained in the area from approximately 7 to 8 p.m. As none of the observers had ever seen a bird like this, they paid particular attention to it. The following are excerpts from a rare bird report that was submitted by observer Kyle Kushnier, via e-mail, to Koes.
"The underside of the bird was completely white with a black trim all the way around the bird. Somebody commented "It looks like a swallow on steroids" because of its deeply forked tail. It would flap its wings just to get above the tree canopy and then would soar for a while above the trees. It was like watching a children's kite fly the way it would move left to right without flapping its wings. It was very active when it flew".

The bird was seen in flight only, always from underneath, and no vocalizations were heard. Unfortunately no photographs were taken. A subsequent search by Kushnier in The Birds of 
Canada $^{2}$ and on the Internet led to the identification of Swallow-tailed Kite. All other observers, including Jason Braun and Donovan Toews, agreed with the identification.

This was the first credible report of the species in Manitoba in over a century. Seton noted that two Swallow-tailed Kites were taken at Winnipeg in 1889 and 1892 and there were a few other reports in the south of the province up to the early 1900s. ${ }^{3}$ Unfortunately, as was often the case in those days, documentation was minimal and the whereabouts of the specimens are unknown. The species was a regular breeder in Minnesota until around 1900, but declined rapidly thereafter and has been a casual visitant since. ${ }^{4}$ Ontario boasts a number of records, but the species has not been reported in Alberta. ${ }^{5,6}$ Although not accepted on the official Saskatchewan list, there are 6 undocumented records from the 1880s to 1955 (A. Smith pers. comm.).

\section{Mississippi Kite}

For most Manitoba birders the highlight of 2014 was the unexpected appearance of a breeding pair of Mississippi Kites in Winnipeg. This was Manitoba's first record of this species and, as far as the authors are aware, the first and only breeding record in Canada, despite the fact that there are 69 records in Ontario (A. Wormington, pers. comm.) and five records in Saskatchewan (A. R. Smith, pers. comm.). This species has been expanding its range northward, at least in part to increasing adaptation to suburban habitat, ${ }^{7}$ and has established breeding "outposts" as far north as Newmarket, New Hampshire (where breeding since 2008). ${ }^{8}$

On 27 July, Michael Loyd reported that he had been observing a raptor in the River Heights area of Winnipeg for 9 days that he felt could be a Mississippi Kite. Many birders flocked to the area and on 28 July John Weier and Donna Martin reported that they had seen not one, but two Mississippi Kites in flight. This prompted discussion on the Manitobabirds listserve about the possibility of a nest nearby and on 31 July two groups of birders, including Michelle Kading, Ray Iverson, Bob Shettler, Michael Loyd and others (one group viewing from a back lane and one from the street) independently located the nest, a small compact cup of sticks approximately $20 \mathrm{~m}$ high in a Bur Oak in a suburban yard, with one downy young.

On 8 August, Artuso estimated the chick to be approximately 24 or 25 days old, and observed it flapping its wings while standing 


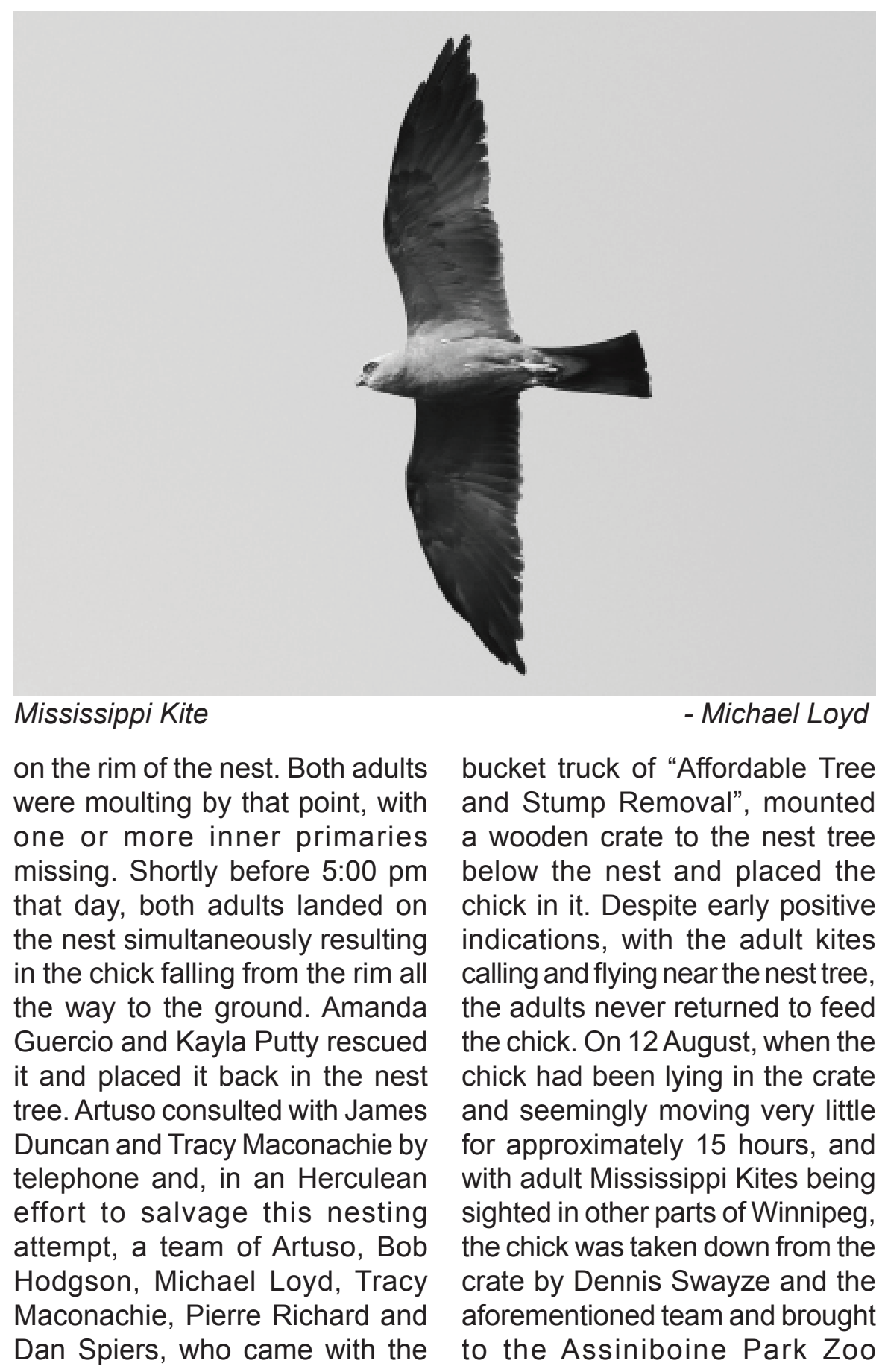


Hospital. The head veterinarian, Dr. Chris Enright, found the chick to be in surprisingly good shape, thin but not emaciated and with reasonably good hydration given the circumstances. The chick recovered well and gained weight in the zoo's care.

Efforts are underway to rehabilitate and release the chick. Mississippi Kites have very low nesting success overall (rural nests average 0.6 fledglings per nest and urban/suburban nests average 1.1 or 1.2 depending on population). ${ }^{9}$ Premature fledging of the chick suggests that the adults were first time parents and the outcome of this nest is perhaps not particularly unusual for this species under these circumstances.

\section{MacGillivray's Warbler}

On 24 May 2014, an unusual Geothlypis warbler was banded and photographed at Delta Marsh Bird Observatory, approximately $25 \mathrm{~km}$ north of Portage La Prairie. The bird was aged by wing and tail condition as a second year, and sexed as female by the pale gray head and chest without dark slaty markings and overall paleness of the breast (A. Guercio, pers. comm.). The photographs suggested MacGillivray's Warbler; the tail being noticeably shorter and the eye arcs being brighter white, thicker, and more restricted than the broken eye ring of female

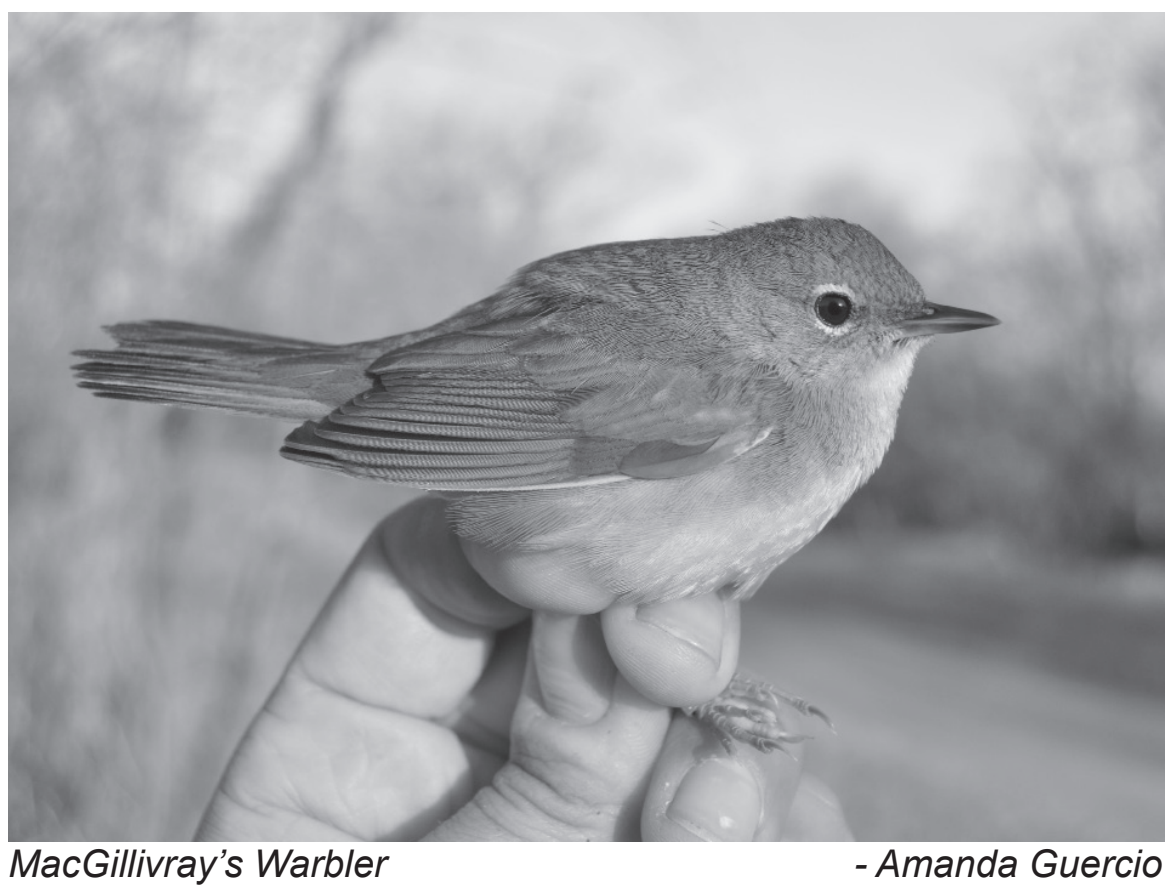




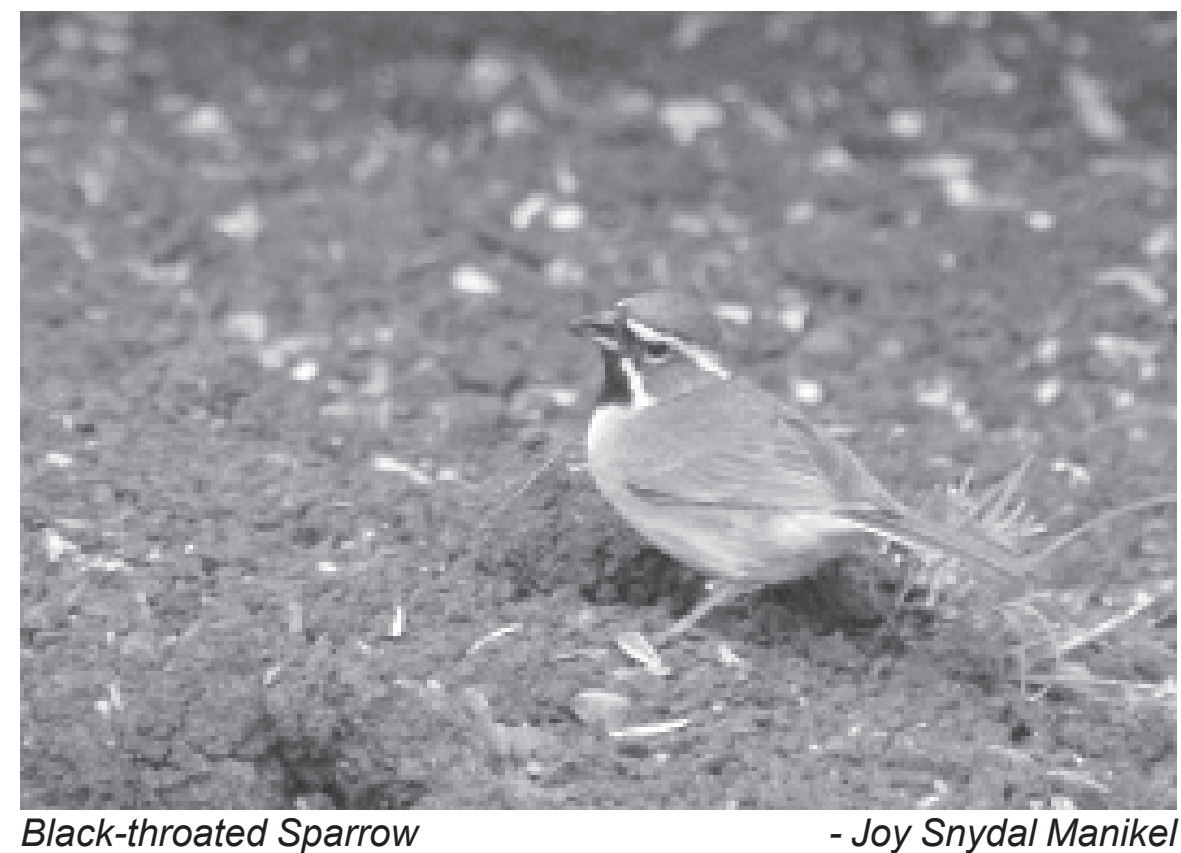

Mourning Warblers. Identification was not confirmed until the bird was retrapped on 26 May. Measurements $(61 \mathrm{~mm}$ wing, $64 \mathrm{~mm}$ flat wing, $54 \mathrm{~mm}$ tail) were out of range for Mourning Warbler (especially a female) and well within MacGillivray's range; flattened wing and tail formula also scored the bird as MacGillivray's. ${ }^{10}$

This is the first confirmed record of MacGillivray's Warbler in Manitoba. A specimen was apparently collected in 1925; however, it was damaged and not preserved. ${ }^{1}$ There are also unconfirmed sight records from May 1943 and 2001.' Given the difficulty in identifying many plumages of MacGillivray's from Mourning Warbler, it is possible that this species has strayed to Manitoba more frequently than these records suggest. This may also be true for Saskatchewan where intensive monitoring at Last Mountain Bird Observatory, a site $370 \mathrm{~km}$ from the species nearest breeding location in the Cypress Hills, has yielded 7 records (A. R. Smith, pers. comm.)

\section{Black-throated Sparrow}

On 6 June, Joy Snydal Manikel photographed Manitoba's first Black-throated Sparrow in her yard near St. Jean-Baptiste (photo). Several Manitoba birders were able to view this bird the next day but it was not recorded after 


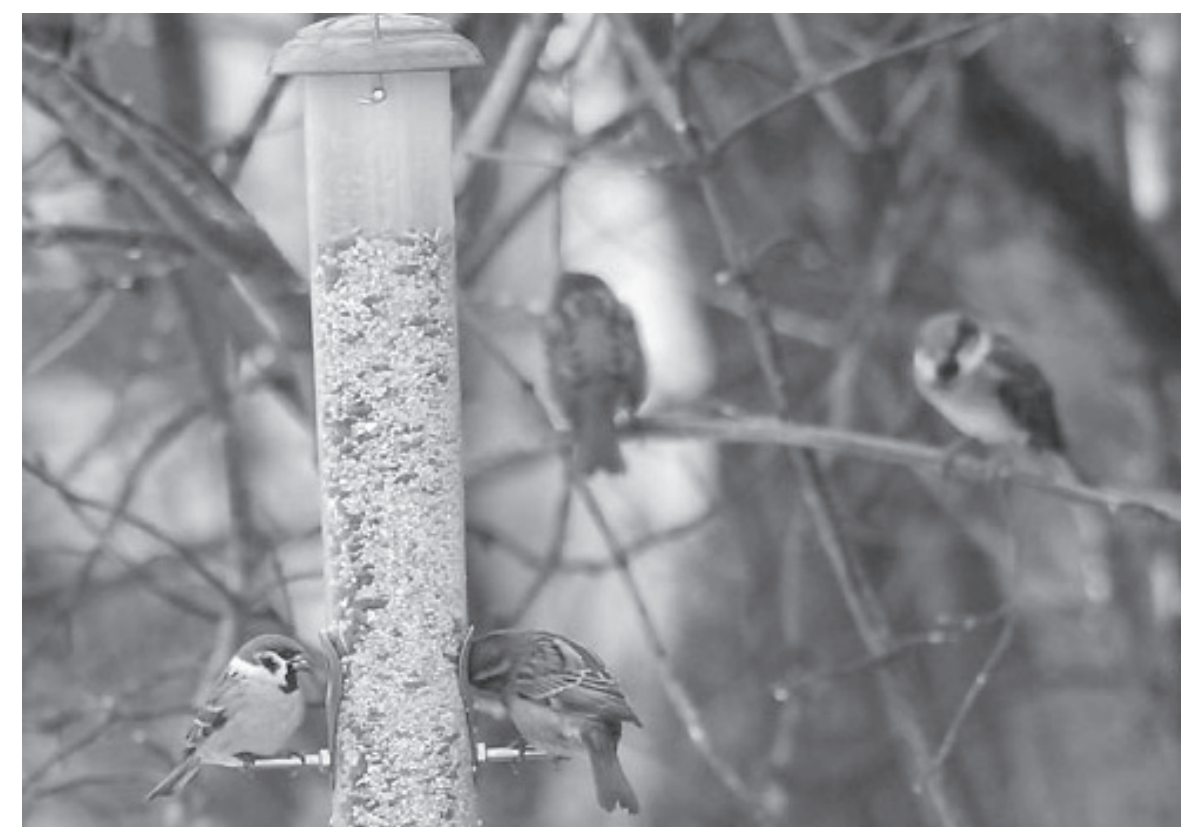

\section{Eurasian Tree Sparrow}

7 June. This species is known to wander, including a record on 6 June 1991 in Hodgeville, Saskatchewan (Joel and Myrna Priebe, B. Luterbach, pers. comm.).

\section{Eurasian Tree Sparrow}

While participating in the Winnipeg Christmas Bird Count on 14 December 2014, Garry Budyk and John Weier discovered a Eurasian Tree Sparrow amongst a large flock of House Sparrows at a feeder in the northwest part of the city. The bird was subsequently seen and photographed by numerous observers and was still present in early February 2015. It represented the fourth record overall, but only the second confirmed sighting, for Manitoba.
There are no Saskatchewan records.

\section{Acknowledgements}

The authors thank M. Loyd for his detailed description of his experience first finding a Mississippi Kite. We also thank the two anonymous reviewers for their thoughtful comments.

1. Manitoba Avian Research Committee (2003) The birds of Manitoba. Manitoba Naturalists Society.

2. Godfrey WE (1986) The birds of Canada. Revised edition. National Museum of Natural Sciences, Ottawa, ON.

3. Seton ET (1908) Recent bird 
records for Manitoba. Auk25:450-454.

4. Kessen AE, Hertzel AX (1999) The historical record of the Swallow-tailed Kite in Minnesota. Loon 71:178-181.

5. Ontario Field Ornithologists (2014) Checklist of the birds of Ontario. 2014. http://www.ofo.ca/ site/page/view/checklist.checklist

6. Royal Alberta Museum (2014) The official list of the birds of Alberta. http://www. royalalbertamuseum.ca/research/ lifeSciences/ornithology/birdlist/ index.cfm

7. Parker, JW (1999) Mississippi Kite (Ictinia mississippiensis), The Birds of North America Online (A. Poole, Ed.). Ithaca: Cornell Lab of Ornithology; Retrieved from the Birds of North America Online: http://bna.birds.cornell.edu/bna/ species/402doi:10.2173/bna.402

8. Swick, N (2014) Mississippi Kite - Manitoba. Retrieved from American Birding Association blog: http://blog.aba . org/2014/08/abarare-mississippikite-manitoba.html

9. Parker, JW (1999) Mississippi Kite (Ictinia mississippiensis), The Birds of North America Online (A. Poole, Ed.). Ithaca: Cornell Lab of Ornithology; Retrieved from the Birds of North America Online: http://bna.birds.cornell.edu/bna/ species/402doi:10.2173/bna.402

10. Pyle, P (1997) Identification guide to North American birds. Part I. Columbidae to Ploceidae. Slate Creek Press.

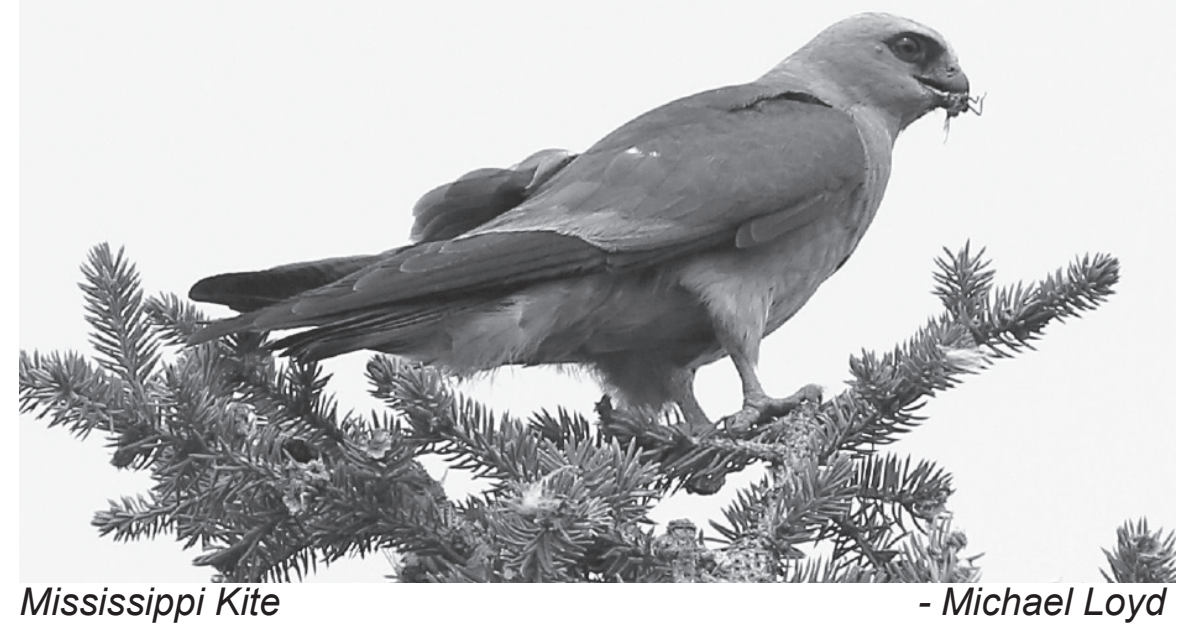

